\title{
Correction to: Pseudomonas fulva HARBPS9.1: candidate anti-Fusarium agent in South Africa
}

\author{
Adetomiwa A. Adeniji (iD • Oluwole S. Aremu • \\ Du Toit Loots • Olubukola O. Babalola (i)
}

Published online: 6 August 2020

(C) Koninklijke Nederlandse Planteziektenkundige Vereniging 2020

\section{Correction to: Eur J Plant Pathol \\ https://doi.org/10.1007/s10658-020-02035-4}

This erratum is to inform readers of an incorrect version of the article was published online first due to vendor errors.

The original publication has been thus corrected.

\section{A. A. Adeniji • O. O. Babalola $(\bowtie)$}

Food Security and Safety Niche Area, Faculty of Natural and Agricultural Science, North-West University, Private Bag X2046, Mmabatho 2735, South Africa

e-mail: olubukola.babalola@nwu.ac.za

\section{O. S. Aremu}

Department of Chemistry, Faculty of Natural and Agricultural Science, North-West University, Private Bag X2046,

Mmabatho 2735, South Africa

A. A. Adeniji · D. T. Loots

Human Metabolomics, Faculty of Natural and Agricultural

Science, Private Bag X6001, Box 269, Potchefstroom 2531, South Africa 